\title{
\begin{tabular}{|l} 
Przeglagd \\
Krytyezny
\end{tabular}
}

\section{O potrzebie krytycznej teorii społeczeństwa}

\author{
MARIUSZ BARANOWSKI
}

Uniwersytet im. Adama Mickiewicza w Poznaniu, ul. Szamarzewskiego 89C, 60-568 Poznań ORCID: 0000-0001-6755-9368,E-mail: mariusz.baranowski@amu.edu.pl

STRESZCZENIE: Zasadniczym celem tekstu jest zwrócenie uwagi na potrzebę krytycznych ujęć szeroko rozumianej rzeczywistości społecznej w naukach społecznych i humanistycznych, szczególnie w czasach ,parametryzacji” i „bibliometryzacji” tych ostatnich. Dyskurs krytyczny operujący „w poprzek” dobrze zinstytucjonalizowanych szkól, podejść czy paradygmatów stanowi wartość także dla - użyjmy określenia Thomasa Kuhna - „nauki normalnej”, która konfrontowana $\mathrm{z}$ alternatywnymi koncepcjami musi być w stanie na nie odpowiedzieć i/lub zreformować swoje podstawy. Krytyczna koncepcja społeczeństwa stanowi zatem wartość nie tylko z perspektywy alternatywnej wizji „,adu społecznego”, ale także z czysto pragmatycznych punktów widzenia zdominowanych aktorów życia społecznego.

SŁOWA KLUCZOWE: teoria krytyczna, nauki społeczne, socjologia krytyczna, szkoła frankfurcka

\section{WPROWADZENIE}

Fundamentem nauk społecznych oraz humanistyki jest krytyczna analiza zastanej rzeczywistości społecznej, której zasadniczy cel polega na przekształcaniu instytucji społecznych w najszerszym tego słowa znaczeniu w taki sposób, by spełniały one oczekiwania artykułowane przez członkinie i członków wspólnoty. Problem polega na tym, że owe oczekiwania same podlegają wpływom ideologicznym, a zatem stanowią element konfrontacji różnych aktorów społeczno-politycznych, reprezentujących odmienne wizje „wspaniałego świata”. Warto w tym miejscu przywołać spostrzeżenie C. Wrighta Mills'a, który w Wyobraźni socjologicznej przypominał, że „nauki społeczne w nieunikniony sposób związane są z procedurami biurokratycznymi i celami ideologicznymi, że związek ten i jego wielopostaciowość mają wpływ na zróżnicowanie i chaos we współczesnych naukach społecznych oraz że jego znaczenie polityczne lepiej byłoby ujawnić, niż ukrywać” (Mills 2007: 155-156). Spostrzeżenie to nie dotyczy wyłącznie nauk społecznych, podobnie rzecz ma się z naukami humanistycznymi i doktrynami praktycznymi (w rodzaju zarządzania). Każda forma zinstytucjonalizowanej formy refleksji 
nad rzeczywistością podlega wpływom ideologicznym, nawet jeśli przybiera formę „,niegroźnych” derywacji w postaci pojęć „,porządku społecznego”, „dobra ogółu” czy „optymalnej formy gospodarowania".

\section{NIE TYLKO SZKOŁA FRANKFURCKA}

Choć krytyczna teoria społeczeństwa i kultury najczęściej utożsamiana jest z działalnością Szkoły Frankfurckiej (Frankfurter Schule), związanej z Institut für Sozialforschung przy Uniwersytecie im. Johanna Wolfganga Goethego, nawiązującej bezpośrednio do tradycji marksizmu, to w niniejszym wprowadzeniu będzie traktowana znacznie szerzej. Dorobek m.in. Maxa Horkheimera, Theodora Adorno, Herberta Marcuse'go, Waltera Benjamina, Ericha Fromma czy Jürgena Habermasa wpisuje się w krytyczną teorię społeczeństwa in toto, jednak nie wyczerpuje całego spektrum możliwych ujęć krytycznych. Bez wątpienia teoria krytyczna szkoły frankfurckiej wywarła i wciąż wywiera wpływ na myślenie o sprzecznościach systemu kapitalistycznego, z faszyzmem, przemysłami kulturalnymi i rozumem instrumentalnym włącznie. Zaś sama „władza przemysłu kulturalnego polega na jego jedności z produkowanymi potrzebami, a nie na prostym przeciwieństwie do potrzeb, choćby ono samo było zarazem przeciwieństwem wszechwładzy i bezsilności. Rozrywka to przedłużenie pracy w późnym kapitalizmie” (Horkheimer, Adorno 2010: 139).

Peter Sloterdijk w Pogardzie mas stwierdził, że „Marx nauczał, że wszelka krytyka zaczyna się od krytyki religii - od Canettiego wypada nauczyć się, że krytyka nie jest rzeczywistą krytyką, jeśli nie prowadzi do zróżnicowania tych »podatności« lub do oddzielenia dobrego zaangażowania od złego" (Sloterdijk 2012: 15). W obu przypadkach mamy do czynienia z odniesieniami do normatywnych struktur funkcjonowania społeczeństw, a pośrednio także z pragmatycznym celem krytyki jako takiej. Nauki społeczne i humanistyczne w drugiej dekadzie XXI wieku wciąż muszą zmagać się z fetyszyzowaną sferą sacrum, jakby Weberowskie drugie odczarowanie świata nigdy nie nastąpiło. Wciąż należy uzasadniać i tłumaczyć się z prospołecznej i aktywnej postawy wobec wykluczających, segregujących, szczujących i otwarcie napastliwych doktryn i poglądów. To jeden z przykładów braku rozwiniętej teorii krytycznej w naukach społecznych i humanistycznych, które to nauki przeistoczyły się w znacznej mierze w ,plemienne” i lokajskie sposoby reprodukcji dominującego - acz wytworzonego - ładu społeczno-politycznego. Jak zauważył David Harvey, „Marksowi przecież zależało na krytycznym poznaniu życia codziennego. Jego metoda wiązała się z »bezlitosną krytyką wszystkiego, co istnieje«" (2016: 119). Brak krytyki natomiast wiąże się z afirmacją lub przyzwoleniem na to, co jest, problem zaś polega na tym, że otaczająca nas rzeczywistość daleka jest od - mówiąc eufemistycznie - ideału.

Bardzo ciekawym wątkiem podjętym przez Sloterdijka jest kwestia, w nawiązaniu do refleksji Canettiego, „ludzkiej czerni”, czyli masy, ludu, motłochu, proletariatu czy opinii publicznej (Sloterdijk 2012: 21). Otóż wedle słów niemieckiego filozofa i teoretyka kultury, „każda przedstawiana publicznie teoria społeczeństwa, nawet jeśli okazuje się krytyczna, mówi chętnie o wszystkim, byle nie o tym wstydliwym zjawisku społeczeństwa jako zbiegowiska, o skandalu 
ludzkiej czerni" (2012: 16). Socjologia krytyczna według owego przykładu ukonstytuowana na konfliktowym modelu społeczeństwa, w którym społeczeństwo przeciwstawione jest państwu, niejako od podstaw dedykowana jest owym masom, w przeciwieństwie do politologii, wpisującej się - poza nielicznymi wyjątkami - w narrację instytucji państwowych (por. Baranowski 2013, 2014a, 2014b, 2016).

Pojęcia podklasy społecznej (underclass) (Welshman 2006), niebezpiecznej klasy (Wallerstein 2004), motłochu (Moll i Pospiszyl 2019), czy przywoływanej wcześniej „ludzkiej czerni” wyznaczają „naturalny” przedmiot zainteresowania socjologii krytycznej, której głównym celem jest eksplikacja tego, co ukrywane w danym systemie ideologicznym, co wyśmiewane, skompromitowane i stygmatyzowane. Socjologia krytyczna to także krytyka nauki jako - użyjmy określenia Horkheimera i Adorna (2010: 91) - „metod reprodukcji ujarzmionego społeczeństwa masowego”. Szczególnie dziś, w czasach zmasowanej krytyki pojęcia wspólnotowości, powinniśmy podejmować trudne zadania demaskowania antyspołecznych tendencji rozsadzających wszelkie przyszłe próby rozsadzenia systemu społecznego w dysfunkcjonalnej postaci. To z kolei wymaga odwagi przeciwstawienia się dominującym opcjom politycznym, jak również tzw. autorytetom naukowym, konserwujących zastaną rzeczywistość społeczną.

\section{KRYTYCZNA TEORIA SPOŁECZEŃSTWA A POZYTYWIZM}

Próba zestawienia - wąsko rozumianej - teorii krytycznej z koncepcją pozytywistyczną (Tabela 1.), pozwala dostrzec szereg istotnych różnic pomiędzy tymi dwoma podejściami. Przede wszystkim teoria krytyczna odrzuca statyczne założenie tradycyjnego podejścia na temat istnienia obiektywnej i uporządkowanej rzeczywistości. Zwolenniczki dynamicznego ujęcia opowiadają się za „mniej komfortową” opcją postrzegania ontologicznych fundamentów rzeczywistości, gdyż w ich wizji jest ona współtworzona przez aktywne podmioty ludzkie. Ma to swoje konsekwencje w warstwie (a) epistemologicznej, w której zwraca się uwagę na relacyjność klasycznego podziału na podmiot i przedmiot poznania, jak również (b) metodologicznej, opartej na odrzuceniu naturalizmu metodologicznego i zastąpieniu go podejściem interdyscyplinarnym. Zasadnicza różnica występuje także na poziomie normatywnym, ponieważ teoria krytyczna neguje postulat wolności od wartościowania (na temat kwestii Wertfreiheit zob. Sartori 1998: 18).

Szerokie rozumienie teorii krytycznej, które wpisuje się w Marksowską „bezwzględną krytykę wszystkiego, co istnieje" (Harvey 2017: 18), wymaga ciągłych przekształceń orientacji ontologiczno-epistemologicznych oraz normatywnych. Krytyczna teoria społeczeństwa, tj. krytyka systemu produkcji, ustroju politycznego, kultury, a także relacji na poziomie mikro-, mezzo- i makrostruktur, musi dysponować złożonymi koncepcjami opisu i wyjaśniania skomplikowanych struktur współczesnych społeczeństw. Powiązania między składowymi elementami społeczeństwa są trwałe i warunkujące się wzajemnie. Jak zauważył Samir Amin w Zmurszałym kapitalizmie, „(...) w centrum kapitalizm będzie musiał zejść ze ścieżek wytyczonych przez opcję neoliberalną (z tego powodu jest ona nie do utrzymania) czy to na lewo, w kierunku nowych postępowych kompromisów społecznych, czy też na prawo, w kierunku faszyzujących 
populizmów narodowych" (Amin 2004: 36). Od kliku lat obserwujemy obie tendencje, choć ta druga z niezwykłą łatwością przebija się do życia społeczno-politycznego.

Tabela 1. Teoria pozytywistyczna vs. krytyczna

\begin{tabular}{|c|c|c|c|}
\hline Założenia & Pytanie & $\begin{array}{c}\text { Teoria pozytywistyczna/ } \\
\text { tradycyjna }\end{array}$ & Teoria krytyczna \\
\hline Ontologiczne & Jaka jest rzeczywistość? & $\begin{array}{l}\text { Rzeczywistość jest upo- } \\
\text { rządkowana; zewnętrzna } \\
\text { wobec badacza. Rzeczy } \\
\text { istnieją obiektywnie } \\
\text { (obiektywizm). }\end{array}$ & $\begin{array}{l}\text { Rzeczywistość nie jest } \\
\text { uporządkowana; jest two- } \\
\text { rzona przez ludzi, w tym } \\
\text { przez badacza. Rzeczy } \\
\text { istnieją intersubiektywnie } \\
\text { (konstruktywizm). }\end{array}$ \\
\hline Epistemologiczne & $\begin{array}{l}\text { Jakie są szanse i granice } \\
\text { poznania rzeczywistości? }\end{array}$ & $\begin{array}{l}\text { Rzeczywistość jest możli- } \\
\text { wa do zbadania; występu- } \\
\text { jące w niej prawidłowości } \\
\text { mogą być odkryte i wyja- } \\
\text { śnione przez badacza. }\end{array}$ & $\begin{array}{l}\text { Szanse poznania rzeczy- } \\
\text { wistości są zawsze ogra- } \\
\text { niczone: sam akt badania } \\
\text { zmienia badaną rzeczy- } \\
\text { wistość; rzeczywistość } \\
\text { podlega ciągłym zmia- } \\
\text { nom; kluczowe znaczenie } \\
\text { w procesie poznania ma } \\
\text { osoba badacza. }\end{array}$ \\
\hline Metodologiczne & $\begin{array}{l}\text { Jakimi metodami można } \\
\text { ją najlepiej badać? }\end{array}$ & $\begin{array}{l}\text { Ideałem jest metodologia } \\
\text { nauk przyrodniczych (na- } \\
\text { turalizm). }\end{array}$ & $\begin{array}{l}\text { Nie istnieje jedna dobra } \\
\text { metoda poznawania rze- } \\
\text { czywistości - zalecany } \\
\text { jest pluralizm metodolo- } \\
\text { giczny (antynaturalizm) } \\
\text { połączony z podejściem } \\
\text { interdyscyplinarnym. }\end{array}$ \\
\hline Normatywne & $\begin{array}{l}\text { Jak powinna wyglądać } \\
\text { pożądana rzeczywistość? }\end{array}$ & $\begin{array}{l}\text { Rzeczywistość jest, jaka } \\
\text { jest; nauka odkrywa jej } \\
\text { istotę i specyfikę, ale nie } \\
\text { wypowiada się na temat } \\
\text { jej pożądanego kształtu. }\end{array}$ & $\begin{array}{l}\text { Rolą teorii jest wskazanie } \\
\text { pożądanego kształtu rze- } \\
\text { czywistości i sposobów } \\
\text { zmiany status quo. }\end{array}$ \\
\hline
\end{tabular}

Źródło: Włoch 2015: 207.

\section{(PARA)DOKSY}

Brak krytycznego namysłu, tudzież systematycznych studiów krytycznych, prowadzi nie tylko do biernej akceptacji rzeczywistości, która „wytwarzana” jest poprzez intencjonalne i nieintencjonalne działania określonych podmiotów (w szerokim sensie), ale również do paradoksalnych konsekwencji funkcjonowania instytucji społecznych. Chodzi przede wszystkim o nieumiejętność dostrzegania możliwości politycznych organizowania działań zbiorowych w ramach istniejących szans instytucjonalnych, jak również na ich obrzeżach. Feminizm stanowi wyśmienitą ilustrację tego zjawiska, gdyż zbudowany jest na krytyce zastanej rzeczywistości, a jednocześnie wewnętrzne tarcia $\mathrm{w}$ ramach tego nurtu (o odmiennym charakterze $\mathrm{w}$ ramach poszczególnych fal) osłabiają realne szanse pełnej emancypacji kobiet. Krytyczna teoria społeczna nie może abstrahować od kwestii najszerzej rozumianego feminizmu, z jego wewnętrznymi podziałami i odmiennymi strategiami działania (por. Spivak 1978; West 1989). Ponad wszelką 
wątpliwość nie sposób odseparować kwestii feministycznych od szerszego kontekstu polityczno-gospodarczego oraz kulturowego, stąd Silvia Federici zauważyła: „Najważniejsze jest to, że nie będziemy w stanie zbudować alternatywnego społeczeństwa i silnego samo-odtwarzającego się ruchu, dopóki nie przedefiniujemy w bardziej kooperatywny sposób naszej reprodukcji oraz dopóki nie skończymy z praktyką oddzielania tego, co jednostkowe [personal] od tego, co polityczne - politycznego aktywizmu od reprodukcji życia codziennego" (Federici 2013: 10).

\section{O POTRZEBIE LUDOWYCH HISTORII}

Howard Zinn swoją Ludowa historia Stanów Zjednoczonych (2016) pokazał, co to znaczy w praktyce używać krytycznego podejścia, a nade wszystko - w sposób niezwykle starannie udokumentowany - przedstawił diametralnie odmienny obraz dziejów tego kraju z perspektywy rzeczywistych ofiar, a nie zwycięzców, którzy posiadają monopol na pisanie historii. Stwierdził: „Nawet godząc się na niedoskonałość mitów, dysponujemy wystarczającą wiedzą, aby - w odniesieniu zarówno do przeszłości, jak i naszych czasów - zakwestionować usprawiedliwianie »postępem « unicestwienia całych ras i opowiadanie historii z punktu widzenia zwycięzców oraz przywódców cywilizacji zachodniej” (Zinn 2016: 52).

Ludowe historie poszczególnych krajów wciąż czekają na ich spisanie, choć pierwsze próby zostały poczynione na długo przed opublikowaniem monumentalnej pracy Howarda Zinna. Christopher Hitchens tak oto opisał opublikowaną w 1791 roku książkę Thomasa Paine'a: ,» Rights of Man« to także rewizjonistyczna wykładnia historii Anglii, napisana z punktu widzenia tych, którzy najmniej uzyskali w wyniku podboju normańskiego i wielowiekowej władzy złych królów" (Hitchens 2008: 18). Uściślając, należy zauważyć, że również obecnie możemy dostrzec namacalne kroki w tym kierunku (zob. Noiriel 2018: 34-37), jak również przymiarki do krytyki zastanej rzeczywistości (zob. Karwat 2017). Postulując potrzebę spisywania „rzeczywistych" historii poszczególnych państw, warto mieć na uwadze pojęcie ideologii, którym posługiwał się Louis Althusser. Otóż francuski marksista twierdził, że ideologia ,stanowi pewien (posiadający swą własną logikę i ścisłość) system przedstawień (mogą to być obrazy, mity, idee czy pojęcia), którym przysługuje istnienie na gruncie danego społeczeństwa i które odgrywają w nim określoną historyczną rolę" (Althusser 2009: 266-267). Takie rozumienie ideologii pozwala zrozumieć nie tylko trwałość utrzymywanych „,narracji” historycznych z perspektywy celów danego państwa, ale również potrzebę krytycznych ich rewindykacji z punktu widzenia ofiar i przegranych. Nie zapominając przy tym o skomplikowanej strukturze oceny zdarzeń historycznych, które mają raczej dialektyczny niż statyczny charakter.

\section{PODSUMOWANIE}

Przywołajmy raz jeszcze Dialektykę oświecenia, w której Horkheimer i Adorno, charakteryzując indywidualizm mieszczaństwa, pisali o „bezwzględności społeczeństwa konkurencji”. Zauważyli oni, że ,jednostka, na której opierało się społeczeństwo, nosiła jego piętno; mimo swej pozornej wolności była produktem ekonomicznej i socjalnej machiny społeczeństwa. Władza, ilekroć potrzebowała aprobaty ze strony pokrzywdzonych przez nią grup, powoływała 
się na panujące stosunki władzy" (Horkheimer, Adorno 2010: 157). Nie sposób uchwycić podstaw krytycznej teorii społeczeństwa bez uwzględnienia wielu poziomów oddziaływań, które krzyżują się w ramach skomplikowanych i dynamicznych struktur zróżnicowania społecznego. Oddziaływania te trudno zidentyfikować pomimo „dość” wyrafinowanych metod analiz oraz olbrzymiej ilości empirycznych danych historycznych. Choć tradycja socjologii krytycznej ma silne powiązania z Marksowskim i Weberowskim ujęciem władzy, która przypisywana jest państwu, to - jak zauważył Noam Chomsky (2018: 15) - sama „władza opiera się zwykle na posłuszeństwie egzekwowanym środkami innymi niż przemoc, nawet tam, gdzie przemoc pozostaje ostatnią deską ratunku".

Dzisiejsze czasy dostarczają nam dowodów na to, że władza - oprócz jej zakamuflowanej i nieprzejrzystej postaci - manifestowana jest w bardzo widoczny i namacalny sposób (por. Žižek 2007). Wojny imperialistyczne, wywoływane konflikty wewnątrzkrajowe wspierane przez hegemoniczne państwa rdzenia, które posługują się także dyscyplinowaniem finansowym za pomocą trojki (Komisja Europejska, Europejski Bank Centralny i Międzynarodowy Fundusz Walutowy), neokolonialne stosunki wyzysku, skutkujące głębokim rozwarstwieniem społecznym krajów najsłabiej rozwiniętych, nie wyczerpują bogactwa (sic!) tego obrazu (Baranowski 2012; Braudel 2013; Husson 2019; Tittenbrun 2012). Dodajmy do tego postępujące ograniczenia praw obywatelskich, nowe wyścigi zbrojeń lub narastające nastroje ksenofobiczne, które są konsekwencją systemowego wsparcia i/lub przychylności dla rasistowskich i faszystowskich organizacji ze strony demokratycznie wybranych sił politycznych. Wszystkie te składowe wraz z ofiarami cywilnymi, głodującymi, uchodźcami, emigrantami, wyzyskiwanymi i eksploatowanymi, zastraszanymi, więzionymi i torturowanymi wymagają krytycznego namysłu nad stanem obecnych stosunków społecznych i ich historycznych poprzedników. Potrzebujemy krytycznych koncepcji społeczeństw ze społeczeństwem globalnym włącznie. Pierre Bourdieu posługiwał się pojęciem filozofii podejrzeń, która miała przypominać, że „wszystkie uniwersalne wartości są w istocie zuniwersalizowanymi wartościami partykularnymi, zatem wzbudzającymi nieufność (kultura uniwersalna to kultura dominująca itd.)" (Bourdieu 2009: 127). Nie tylko filozofia, ale każda forma refleksji nad społeczeństwem musi kierować się owymi podejrzeniami, szczególnie przy eksploracji zinternalizowanych struktur rzeczywistości społecznej, której stanowimy cząstkę.

\section{BIBLIOGRAFIA}

Althusser, Louis. 2009. W imię Marksa. Tłum. M. Herer. Warszawa: Wydawnictwo Krytyki Politycznej.

Amin, Samir. 2004. Zmurszały kapitalizm. Tłum. R. Wojna i Z. M. Kowalewski. Warszawa: Wydawnictwo Akademickie DIALOG.

Baranowski, Mariusz i Grażyna Musiał. 2012. Teoretyczny i empiryczny wymiar badania koniunktury. W: G. Musiał (red.). Wybrane problemy koniunktury, wzrostu gospodarczego oraz konkurencji w teorii i praktyce. Katowice: Wydawnictwo Uniwersytetu Ekonomicz- 
nego w Katowicach, s. 13-33.

Baranowski, Mariusz. 2013. Between Social Control and Conflict: An Analytical Framework for Social Movements. „Acta Universitatis Lodziensis. Folia Sociologica” 47: 5-16.

Baranowski, Mariusz. 2014a. Wprowadzenie do socjologicznego ujęcia problemu demokracji i roli obywatela. W: M. Baranowski (red.). Demokracja i rola obywatela. O napięciu pomiędzy państwem, społeczeństwem i procesami globalizacyjnymi. Poznań: Wydawnictwo Naukowe Wydziału Nauk Społecznych UAM, s. 9-14.

Baranowski, Mariusz. 2014b. W stronę konfliktowego modelu polityczności. W: M. Baranowski (red.). Demokracja i rola obywatela. O napięciu pomiędzy państwem, społeczeństwem $i$ procesami globalizacyjnymi. Poznań: Wydawnictwo Naukowe Wydziału Nauk Społecznych UAM, s. 81-91.

Baranowski, Mariusz. 2016. Socjologiczny wymiar państwa dobrobytu. W: M. Baranowski, P. Cichocki i M. Maraszkiewicz (red.). Przestrzeń publiczna i państwo dobrobytu. Poznań: Wydawnictwo Naukowe Wydziału Nauk Społecznych UAM, s. 59-72.

Bourdieu, Pierre. 2009. Rozum praktyczny. O teorii działania. Tłum. J. Stryjczyk. Kraków: Wydawnictwo Uniwersytetu Jagiellońskiego.

Braudel, Fernand. 2013. Dynamika kapitalizmu. Tłum. B. Baran. Warszawa: Wydawnictwo Aletheia.

Chomsky, Noam. 2018. Siła i opinia. Tłum. M. Jedliński. Warszawa: Instytut Wydawniczy Książka i Prasa.

Federici, Silvia. 2013. Feminizm i polityka dóbr wspólnych w erze akumulacji pierwotnej. Biblioteka Online Think Tanku Feministycznego 2013, http://www.ekologiasztuka.pl/pdf/ federici_feminizm_i_polityka_dobr_wspolnych.pdf [Dostęp 11.07.2019].

Foucault, Michel. 1998. Trzeba bronić społeczeństwa. Wykłady w Collège de France, 1978. Tłum. M. Kowalska. Warszawa: Wydawnictwo KR.

Fromm, Erich. 2007. Ucieczka od wolności. Tłum. O. i A. Ziemilscy. Warszawa: Spółdzielnia Wydawnicza „Czytelnik”.

Harvey, David. 2016. Przestrzenie globalnego kapitalizmu. W stronę teorii rozwoju nierównego geograficznie. Tłum. J. P. Listwan. Warszawa: Instytut Wydawniczy Książka i Prasa.

Hitchens, Christopher. 2008. Thomas Paine. Prawa człowieka. Bibliografia. Tłum. J. Dzierzgowski. Warszawa: Warszawskie Wydawnictwo Literackie MUZA SA.

Horkheimer, Max i Theodor W. Adorno. 2010. Dialektyka oświecenia. Fragmenty filozoficzne. Tłum. M. Łukasiewicz. Warszawa: Wydawnictwo Krytyki Politycznej.

Horkheimer, Max. 2007. Krytyka instrumentalnego rozumu. Tłum. H. Walentowicz. Warszawa: Wydawnictwo Naukowe Scholar.

Horkheimer, Max. 1987. Społeczna funkcja filozofii. Wybór pism. Tłum. J. Doktór. Warszawa: Państwowy Instytut Wydawniczy.

Husson, Michel. 2019. Jak zerwać z kapitalizmem. Studia o kryzysie światowym i strategii lewicy. Tłum. Z. M. Kowalewski. Warszawa: Instytut Wydawniczy Książka i Prasa.

Karwat, Mirosław. 2017. Autorytaryzm a populizm. Zarys wspótzależności. W: F. Pierzchalski 
i B. Rydliński (red.). Autorytarny populizm w XXI wieku. Krytyczna rekonstrukcja. Warszawa: Dom Wydawniczy ELIPSA, s. 15-32.

Kuhn T. S. (1968). Struktura rewolucji naukowych. Tłum. H. Ostromęcka. Warszawa: Państwowe Wydawnictwo Naukowe.

Lipset S. M. (1998). Homo politicus. Społeczne podstawy polityki. Tłum. G. Dziurdzik-Kraśniewska. Warszawa: Wydawnictwo Naukowe PWN.

Mills, C. Wright. 2007. Wyobraźnia socjologiczna. Tłum. M. Bucholc. Warszawa: Wydawnictwo Naukowe PWN.

Moll, Łukasz i Michał Pospiszyl. 2019. Filozofia polityczna motłochu. „Le Monde diplomatique" 1(155): 5-7.

Noiriel, Gérard. 2018. Ludowa historia Francji. „Le Monde diplomatique” 8(150): 34-37.

Sartori G. (1998). Teoria demokracji. Tłum. P. Amsterdamski i D. Grinberg. Warszawa: Wydawnictwo Naukowe PWN.

Sloterdijk, Peter. 2012. Pogarda mas. Tłum. B. Baran. Warszawa: Wydawnictwo Aletheia.

Spivak, Gayatri. 1978. Feminism and Critical Theory. „Women's Studies International Quarterly" 1(3): 241-246. https://doi.org/10.1016/S0148-0685(78)90170-7

Tittenbrun, Jacek. 2012. Gospodarka w społeczeństwie. Zarys socjologii gospodarki i socjologii ekonomicznej w ujęciu strukturalizmu socjoekonomicznego. Poznań: Zysk i S-ka Wydawnictwo.

Wallerstein, Immanuel. 2004. Koniec świata jaki znamy. Tłum. M. Bilewicz i in. Warszawa: Wydawnictwo Naukowe Scholar.

Welshman, John. 2006. Underclass: A History of the Excluded Since 1880-2000. London-New York: Hambledon Continuum.

West, Robin. 1989. Feminism, Critical Social Theory and Law. „University of Chicago Legal Forum" 1989(1): 59-97.

Włoch, Renata. 2015. Teoria krytyczna. W: R. Zięba, J. Zając i S. Bieleń (red.). Teorie i podejścia badawcze w nauce o stosunkach międzynarodowych. Warszawa: Wydział Dziennikarstwa i Nauk Politycznych Uniwersytet Warszawski, s. 201-216.

Zinn, Howard. 2016. Ludowa historia Stanów Zjednoczonych. Od roku 1492 do dziś. Tłum. A. Wojtasik. Warszawa: Wydawnictwo Krytyki Politycznej.

Žižek, Slavoj. 2007. Rewolucja u bram. Pisma Lenina z roku 1917. Tłum. J. Kutyła. Kraków: Korporacja Ha!art. 


\section{The need for a critical theory of society}

ABSTRACT: The main aim of the article is to draw attention to the need for critical approaches to the broadly understood social reality in social sciences and humanities, especially in the times of "parameterization" and "bibliometrization" of the latter. A critical discourse that operates ,across” well-instituted schools, approaches or paradigms is also of value to - let's use Thomas Kuhn's term - "normal science", which when confronted with alternative concepts must be able to respond to them and/or reform its foundations. A critical concept of society is therefore a value not only from the perspective of an alternative vision of "social order", but also from the purely pragmatic points of view of dominated social actors.

KEYWORDS: critical theory, social sciences, critical sociology, the Frankfurt school 